\begin{tabular}{c} 
International Journal of Scientific World, $4(1)(2016) 11-14$ \\
International Journal of Scientific World \\
SPC \\
Website: $\begin{array}{c}\text { www. sciencepubco.com/index.php/IJSW } \\
\text { doi: } 10.14419 / \text { ijsw.v4i } 1.5845 \\
\text { Research paper }\end{array}$ \\
\hline
\end{tabular}

\title{
Phytochemical analysis and proximate composition of Vernonia amygdalina
}

\author{
Usunobun Usunomena ${ }^{1}$, Okolie P. $\operatorname{Ngozi}^{2}$ \\ ${ }^{I}$ Department of Basic sciences (Biochemistry unit), Faculty of Basic and Applied sciences, Benson Idahosa University, \\ P.M.B 1100, Benin City, Edo state, Nigeria \\ ${ }^{2}$ Department of Biochemistry, Faculty of Life sciences, University of Benin, Benin city \\ *Corresponding authorE-mail:uusunobun@biu.edu.ng
}

\begin{abstract}
Background: Vernonia amygdalina is used to prepare dishes as well as a multi-purpose fodder tree with high biomass yield. This study was conducted to determine phytochemicals and proximate composition of Vernonia amygdalina leaves.

Methods: Evaluation of Vernonia amygdalina for phytochemicals and proximate composition were conducted using standard methods.

Results: Result showed that Vernonia amygdalina contain phytochemicals such as alkaloids, tannins, flavonoids, saponins, triterpenoids, steroids, cardiac glycosides, and reducing sugar. Results obtained on the proximate composition shows that Vernonia amygdalina in percentage $(\%)$ contain dry matter $(90.68 \pm 0.77)$, crude protein $(22.81 \pm 0.17)$, crude fiber $(18.17 \pm 0.06)$, moisture $(9.32 \pm 0.67)$, ash $(16.65 \pm 0.09)$, crude fat $(4.34 \pm 0.04)$ and carbohydrate $(38.03 \pm 0.06)$.

Conclusion: The presence of phytochemicals like saponins, tannins, alkaloids and flavonoids explains the medicinal potentials of Vernonia amygdalina leaves in therapeutic uses. Also the leafy vegetables if consume in sufficient amount would contribute greatly to the nutritional requirement for human health and to the food security of Nigerian population.
\end{abstract}

Keywords:Vernonia amygdalina; Phytochemicals; Proximate; Ethanol.

\section{Introduction}

Vernonia amygdalina, variously known as bitter leaf (English), oriwo (Edo), ewuro (Yoruba), shikawa (Hausa), and olubu (Igbo), is a tropical shrub, $1-3 \mathrm{~m}$ in height with petiole leaf of about $6 \mathrm{~mm}$ in diameter, and elliptic in shape [1]. The leaves are dark green coloured with a characteristic odour and a bitter taste. The species is indigenous to tropical Africa and is found wild or cultivated all over sub- Saharan Africa [2]. The leaves are eaten, after crushing and washing thoroughly to remove the bitterness [3]. All parts of the plant are pharmacologically useful. Both the roots and leaves are used in phyto-medicine to treat fever, hiccups, kidney disease and stomach discomfort, among others [4]. The stem and root divested of the bark are used as chew-sticks in Nigeria. More importantly, the leaves are used to prepare the very popular bitter leaf soup in Nigeria, and are also reportedly consumed by goats in some parts of Nigeria [5]. Antihelmitic and antimalarial properties [6] as well as antitumourigenic properties [7], have also been reported for extracts from the plant. Other studies have demonstrated hypoglycaemic and hypolipidaemic effects of the leaf extract in experimental animals [8-10]. This study was conducted to determine nutritional and physicochemical properties Vernonia amygdalina leaves.

\section{Materials and methods}

2.1. Collection, identification and preparation of plant materials

Vernonia amygdalina leaves were purchased from a local market in Benin City, Edo state, Nigeria. The fresh leaves were identified, separated from the stalk, washed and air-dried at room tempera- ture $\left(24^{\circ} \mathrm{C}\right)$ and then pulverized, crushed into fine powder and weighed.

\subsection{Extraction of the plant leaves}

Ethanolic extracts of the Vernonia amygdalina leaves was prepared by soaking $400 \mathrm{~g}$ of the dry powdered plant leaves in $1000 \mathrm{ml}$ of absolute ethanol at room temperature for $48 \mathrm{hrs}$. The extract was thereafter filtered first through a Whatmann filter paper No. 42 $(125 \mathrm{~mm})$ and then through cotton wool. The extract was then concentrated using a rotary evaporator with the water bath set at $40{ }^{\circ} \mathrm{C}$ to one-tenth its original volume and finally with a freeze drier. The dried residue was then stored at $4^{\circ} \mathrm{C}$. Portions of the crude plant extract residue were weighed and dissolved in distilled water for experimental analysis.

\subsection{Methods for proximate analysis}

The dry matter, moisture, ash, crude fat, crude protein (nitrogen $\mathrm{x}$ 6.25) and crude fibre contents were determined in powdered Vernonia amygdalina leaves using the standard methods of the Association of Official Analytical Chemists [11] while carbohydrate content was calculated based on the net difference between the other nutrients and the total percentage composition.

\subsection{Methods for phytochemical screening}

Phytochemical screening was performed using standard procedures [12-14]. 


\subsubsection{Test for saponins}

To $0.5 \mathrm{~g}$ of extract, $5 \mathrm{ml}$ of distilled water was added in a test tube and the solution shaken vigorously and observed for a stable persistent froth. The frothing was mixed with 3 drops of olive oil and shaken vigorously after which it was observed for the formation of an emulsion.

\subsubsection{Test for triterpenoids}

$0.5 \mathrm{~g}$ of the extract was dissolved in $1 \mathrm{ml}$ of chloroform and $1 \mathrm{ml}$ acetic anhydride added, followed by the addition of $2 \mathrm{ml}$ of concentrated $\mathrm{H}_{2} \mathrm{SO}_{4}$. Triterpenoids was indicated by formation of reddish violet colour.

\subsubsection{Test for tannins}

About $0.5 \mathrm{~g}$ of the extract was boiled in $10 \mathrm{ml}$ of water in a test tube and then filtered. A few drops of $0.1 \%$ ferric chloride was added and the solution observed for brownish green or a blueblack colouration

\subsubsection{Test for reducing sugar (fehling' $s$ test)}

$0.5 \mathrm{~g}$ of the extract was dissolved in $5 \mathrm{ml}$ distilled water and filtered. The filtrate was hydrolysed with dilute $\mathrm{HCl}$, neutralized with alkali $(\mathrm{NaOH})$ and heated with Ferling`s A and B solutions. Formation of red precipitate indicated the presence of reducing sugars.

\subsubsection{Test for anthraquinones}

$0.5 \mathrm{~g}$ of the extract was boiled with $10 \mathrm{ml}$ of $\mathrm{H}_{2} \mathrm{SO}_{4}$ and filtered while hot. The filtrate was shaken with $5 \mathrm{ml}$ of chloroform, the chloroform layer was pipette into another test tube and $1 \mathrm{ml}$ of dilute ammonia was added. The resulting solution was observed for colour changes.

\subsubsection{Test for steroids}

$0.5 \mathrm{~g}$ of the extract was dissolved in $10 \mathrm{ml}$ of chloroform and equal volume of concentrated $\mathrm{H}_{2} \mathrm{SO}_{4}$ was added by the sides of the test tubes. Reddish upper layer and yellowish sulphuric acid layer with green fluorescence indicate the presence of steroids.

\subsubsection{Test for cardiac glycosides (keller-killiani test)}

To $0.5 \mathrm{~g}$ of extract dissolved in $5 \mathrm{ml}$ water was added $2 \mathrm{ml}$ of glacial acetic acid solution containing one drop of ferric chloride solution This was underlayed with $1 \mathrm{ml}$ of concentrated $\mathrm{H}_{2} \mathrm{SO}_{4}$. A brown ring at the interface indicated the presence of a deoxysugar characteristics of cardenolides. A violet ring may appear below the brown ring while in the acetic acid layer a greenish ring may form just above the brown ring and gradually spread throughout this layer.

\subsubsection{Test for flavonoids}

Dilute ammonia $(5 \mathrm{ml})$ was added to a portion of an aqueous filtrate of the extract. Then, concentrated sulphuric acid $(1 \mathrm{ml})$ was added. A yellow colouration indicated the presence of flavonoids.

\subsubsection{Test for alkaloids}

Extract was dissolved in dilute $\mathrm{HCl}$ and filtered. Filtrates were treated with Mayer`s reagent (potassium mercuric iodide). Formation of a yellow coloured precipitate indicates the presence of alkaloids.

\section{Results and discussion}


that a high intake of dietary fiber is associated with enhanced insulin sensitivity and therefore may have a role in the prevention and control of Type 2 diabetes. The substantial amount of fibre in Vernonia amygdalina leaves shows that they can help in keeping the digestive system healthy and functioning properly.

Vernonia amygdalina had ash value of $16.65 \%$ which is a reflection of the mineral contents preserved in the plants leaf. The ash content obtained compare favorably with the values reported for Vernonia colorate (15.86\%) and Moringa oleifera (15.09\%) [31], [37] and lower than that of some leafy vegetables commonly consumed in Nigeria such as Talinum triangulare $(20.05 \%)$ but higher than some other vegetables such as Occimum graticimum $(8.00 \%)$ and Hibiscus esculentus $(8.00 \%)$ [30]. the result therefore suggests a high deposit of mineral elements in the leaves [31].

Vernonia amygdalina had carbohydrate value of $38.03 \%$, lower than reported values for Corchorus tridens $(75.0 \% \mathrm{DW})$ and sweet potatoes leaves $(82.8 \%$ ) [38] but higher than $20 \%$ and $23.7 \%$ reported for Senna obtusfolia and Amaranthus incurvatus respectively [27, 39]. Thus the high carbohydrate content contributes the highest Kilojoules to the energy value in Vernonia amygdalina. Carbohydrates produced by plants are one of the three main energy sources in food, along with protein and fat. When animals eat plants, energy stored in carbohydrates is released by the process of respiration, a chemical reaction between glucose and oxygen to produce energy, carbon dioxide, and water.

Vernonia amygdalina had a crude fat value of $4.34 \%$ which was in agreement with Yeap et al (26) reported crude fat value range of 2 to $15 \%$. Also the $4.34 \%$ Vernonia amygdalina crude fat value obtained compares favourably when compared to those of Talinum triangulare $(5.90 \%)$, BaseilaAlba (8.71\%), Amaranthus hybridus (4.80\%), Calchorus africanum (4.20\%) [30]. A diet providing 1 $2 \%$ of its caloric of energy as fat is said to be sufficient for human being as excess fat consumption is implicated in certain cardiovascular disorders [31].

The moisture content value of Vernonia amygdalina leaves was relatively low. The low moisture content would therefore hinder the growth of spoilage microorganisms and enhance shelf life.

Table 2: Proximate Analysis of Vernonia amygdalina Leaves

\begin{tabular}{ll}
\hline Proximate composition & Vernonia amygdalina $(\%)$ \\
\hline Dry matter & $90.68 \pm 0.77$ \\
Moisture Content & $9.32 \pm 0.67$ \\
Crude protein & $22.81 \pm 0.17$ \\
Crude fiber & $18.17 \pm 0.06$ \\
Ash content & $16.65 \pm 0.09$ \\
Crude fat/oil & $4.34 \pm 0.04$ \\
Carbohydrate & $38.03 \pm 0.06$ \\
\hline
\end{tabular}

Values are means \pm SD for 3 determinations.

In conclusion, the broad distribution of nutrients and phytochemicals in the Vernonia amygdalina leaves studied support, as well as provide a basic rationale for their use as in folk medicine. This study also indicates that Vernonia amygdalina leaves, besides serving as good source of pharmacologically active phytochemicals may also be useful as supplements in human and animal nutrition.

\section{References}

[1] Igile GO, Oleszek W, Jurzysta M, Burda S, Fafunso M, \& Fasanmade AA. (1995). Nutritional assesment of Vernonia amygdalina leaves in growing mice. Journal of Agriculture and Food Chemistry43, 2162-2166.http://dx.doi.org/10.1021/jf00056a038.

[2] Bosch CH, Borus DJ \& Siemonsma JS. (2005). Vegetables of Tropical Africa. Conclusions and Recommendations Based on PROTA 2: 'Vegetables'. PROTA Foundation, Wageningen, Netherlands. 10 modules, pp68.

[3] Mayhew S \& Penny A. (1988). Macmillan Tropical and Subtropical Foods. Macmillan Publishers, London, p107.

[4] Gill LS (1992). Ethnobotanical uses of plants in Nigerial. University of Binin press, Benin City, 350.
[5] Argheore EM, Makkar HPS \& Becker K. (1998). Feed value of some browse plants from the central zone of Delta State Nigeria. Tropical Science38(2), 97-104.

[6] Abosi AO \&Raseroka BH. (2003). In vivo antimalarial activity of Vernonia amygdalina. British Journal of Biomedical Science 60(2), 89- 91.

[7] Izevbige EB, Bryant TL, \& Walker AA (2004). novel natural hibitor of extracellular signal regulated kinases and human breast cancer cell growth. Experimental Biology andMedicine 229(2), 163 169.

[8] Akah PA \& Okafor CI (1992).Hypoglycemic effect of Vernonia amygdalina in experimental rabbits Plant Medicine andResearch1, 6-10.

[9] Nwanjo HU (2005). Efficacy of aqueous leaf extract of Vernonia amygdalina on plasma lipoprotein and oxidative status in diabetic ratmodels. Nigerian Journal of Physiological Science 20, 39-42.

[10] Ebong PE, Atangwho IJ, Eyong EU, \&Egbung GE. (2008). the antidiabetic efficacy of combined extracts from two continental plants: Azadirachta indica(A. Juss) (Neem) and Vernonia amygdalina (Del.) (African bitter leaf). American Journal of Biochemistry and Biotechnology 4, 239244.http://dx.doi.org/10.3844/ajbbsp.2008.239.244.

[11] AOAC (Association of Official Analytical Chemists). (2000). Official method of analysis. 15th Edition, Washington D.C. p212.

[12] Sofowora LA. (1993). Medicinal plants and Traditional Medicine in Africa. Spectrum Books Ltd, Ibadan, pp55-71.

[13] Trease GE \& Evans WC. (1985). Pharmacognosy 11th Ed., Tindall Ltd, London, pp60-75.

[14] Ayoola, GA, Coker HAB, Adesegun SA, Adepoju-Bello AA, Obaweya K, Ezennia EC \&Atangbayila TO. (2008).Phytochemical screening and antioxidant activities of some selected medicinal plantsused for malarial therapy in South-Western Nigeria. Tropical Journal ofPharmaceutical Research 7, 1019-1024.

[15] Ugwu OPC, Nwodo OFC, Joshua PE, Bawa A, Ossai EC \&Odo CE.(2013). Phytochemical and Acute Toxicity Studies of MoringaoleiferaEthanol Leaf Extract. International Journal of Life SciencesBiotechnology and Pharma Research 2(2), 66-71.

[16] Aiyegoro OA \&Okoh AI. (2009). Phytochemical screening and polyphenolic antioxidant activity of aqueous crude leaf extract of Helichrysumpedunculatum. International Journal of Molecular Science 10, 4990-5001.http://dx.doi.org/10.3390/ijms10114990.

[17] Omoregie ES,Osagie AU \& Iruolaje EO (2011). In Vitro Antioxidant Activity And The Effect Of Methanolic Extracts Of Some Local Plants On Nutritionally Stressed Rats. Pharmacologyonline1, 23-56.

[18] Haslam E. (1996). Natural Polyphenols (vegetable tannins) as drugs: possible modes of action. Journal of National Productivity 59, 205- 215.http://dx.doi.org/10.1021/np960040+.

[19] Okwu DE. \& Emenike IN. (2006). Evaluation of the phytonutrients and vitamin contents of Citrusfruits. International Journal ofMolecular Medicine and Advance Sciience 2, 1-6.

[20] Adegboye MF, Akinpelu DA. \&Okoh, A. (2008). The bioactive and phytochemical properties of Garcinia kola (Heckel) seed extract on some pathogens. African Journal of Biotechnology 7(21), 39343938.

[21] Harbone, JB. (1998). Methods of extraction and isolation. In: Phytochemical Methods. Chapman and Hall, London;Pp60-66.

[22] Francis C, George G, Zohar K, Harinder PS, Makhar LM, \& Klaus B. (2002). The biological action of saponins in animal system: a review. British Journal of Nutrition88(6),5876051.http://dx.doi.org/10.1079/BJN2002725.

[23] Okwu DE.(2001).Evaluation of the chemical composition of medicinal plants belonging to Euphorbiaceae. Pakistan Veterinary Journal $14,160-162$.

[24] Aiyegoro OA. \&Okoh AI. (2010). Preliminary phytochemical screening and in vitro antioxidant activities of the aqueous extract of Helichrysum longifoliumDC. BMC Complementary and Alternative Medicine 10, 21-32.http://dx.doi.org/10.1186/1472-6882-1021

[25] Yukari I, Youichi F, Ikuko N, \&Itsuru Y. (1995). Quantitative HPLC analysis of cardiac glycosides in Digitalis purpurealeaves. JournalNational Productivity58(60), 897-901.

[26] Yeap SK, Ho WY, Beh BK, Liang WS, Ky H, Yousr AHN \&Alitheen, NB. (2010). Vernonia amygdalina, an ethnoveterinary and ethnomedical used green vegetable with multiple bio- activities. Journal of Medicinal Plants Research 4(25), 2787-2812.

[27] Hassan LG \& Umar KJ (2006).Nutritional value of Balsam Apple (Momordica balsaminaL.) leaves. Pakistan Journal Nutrition 5(6), 522-529.http://dx.doi.org/10.3923/pjn.2006.522.529. 
[28] Isong EU. AndIdiong. (1997). Comparative studies on the nutritional and toxic composition of three varieties of Leianthera Africana, Plants.Food and Human Nutrition51, 7984.http://dx.doi.org/10.1023/A:1007922308985.

[29] Ogle BM \& Grivetti LE (1985).Legacy of the chameleon: Edible wild plants in the Kingdom of Swaziland, Southern Africa. A cultural, ecological nutritional study. Part IV: Nutritional analysis and conclusion, Ecology and Food. Nutrition17, 4164.http://dx.doi.org/10.1080/03670244.1985.9990881.

[30] Akindahunsi AA \& Salawu.SO. (2005). Photochemical screening and nutrient-anti-nutrient composition of selected tropical greenvegetables, African Journal of Biotechnology4, 497-501

[31] Antia BS, Akpan EJ, Okon PA \&Umoren IU.(2006). Nutritive and Anti-Nutritive Evaluation of Sweet Potatoes (Ipomoea batatas) Leaves. Pakistan Journal of Nutrition5,166168http://dx.doi.org/10.3923/pjn.2006.166.168.

[32] Etuk EU, Bassey MN, Umoh UO \& Inyang EG. (1998). Comparative nutritional studies on three local varieties of Heinsiacrinita Plant Varieties Seeds11, 151-158.

[33] Bailey R (2008), the Role of Proteins in the Body. About.com Guide to Biology.

[34] Mensah JK, Okoli RI, Ohaju-Obodo JO and Eifediyi K (2008).Phytochemical, nutritional and medical properties of some leafy vegetables consumed by Edo people of Nigeria. African Journal of Biotechnology7, 2304-2309.

[35] Henry S. (2004). Fiber: An All Natural "Medicine" for Type 2 Diabetes? Consumer Health Interactive.http://www.ahealthyme.com

[36] Ylonen K, Saloranta C, Kronberg C, Leif G, Antti A, Suvi M, \&Virtanean M. (2003). Associations of Dietary Fiber with Glucose Metabolism in Non-diabetic relatives of subjects with Type 2 Diabetes. Diabetes care 19791985.http://dx.doi.org/10.2337/diacare.26.7.1979.

[37] Lockeett CT, CalvertCC and Grivetti LE (2005). Energy and micronutrient Composition of dietary and Medicinal wild plants Consumed during drought: Study of Rural Fulani, Northeastern Nigeria. International Journal ofFood. Science and Nutrition51, 195-208.

[38] Asibey-BerkoE,\&Tayie FAK. (1999). Proximate Analysis of some under -utilized Ghanian vegetables. Ghana Journal ofScience 39, 816.

[39] Faruq UZ, Sani A and Hassan LG (2002). Proximate composition of sickle pod. (Senna obtusfolia) leaves,Nigerian Journal of Basic andApplied Sciences11, 157-164. 